\title{
Back to Ecology: Reference Conditions as a Basis for Assessment, Restoration and Sustainable Management of Large Rivers
}

\author{
Gorazd Urbanič ${ }^{1,2, *}$, Zlatko Mihaljević ${ }^{3}\left(\mathbb{D}\right.$, Vesna Petkovska ${ }^{4}$ and Maja Pavlin Urbanič ${ }^{1}$ \\ 1 URBANZERO Institute for Holistic Environmental Management, Ltd., Selo pri Mirni 17, \\ 8233 Mirna, Slovenia; maja@urbanzeroinstitute.com \\ 2 Biotechnical Faculty, University of Ljubljana, Jamnikarjeva 101, 1000 Ljubljana, Slovenia \\ 3 Department of Biology, Faculty of Science, University of Zagreb, Rooseveltov Trg 6, 10000 Zagreb, Croatia; \\ zlatko.mihaljevic@biol.pmf.hr \\ 4 Ministry of the Environment and Spatial Planning, Dunajska Cesta 48, 1000 Ljubljana, Slovenia; \\ vesna.petkovska@gov.si \\ * Correspondence: gorazd@urbanzeroinstitute.com
}

Citation: Urbanič, G.; Mihaljević, Z.; Petkovska, V.; Pavlin Urbanič, M.

Back to Ecology: Reference

Conditions as a Basis for Assessment, Restoration and Sustainable Management of Large Rivers. Water 2021, 13, 2596. https://doi.org/ 10.3390/w13182596

Academic Editor: Rui Cortes

Received: 10 August 2021

Accepted: 18 September 2021

Published: 20 September 2021

Publisher's Note: MDPI stays neutral with regard to jurisdictional claims in published maps and institutional affiliations.

Copyright: (c) 2021 by the authors. Licensee MDPI, Basel, Switzerland. This article is an open access article distributed under the terms and conditions of the Creative Commons Attribution (CC BY) license (https:/ / creativecommons.org/licenses/by/ $4.0 /)$.

\begin{abstract}
Under the EU Water Framework Directive, ecological assessment and management are based on type-specific reference conditions. In the EU it may be difficult to find sites in large rivers with at least near-natural conditions, though this is not the case in southeast Europe, where stretches of large rivers still exist with at least near-natural conditions, meaning that there is little or no disturbance from hydromorphological alteration, water quality, land use in the catchment and alien species. We examined benthic invertebrate assemblages in 45 samples collected from near-natural sites of several large rivers: Sava, Drava, Mura, Kupa and Una. The near-natural benthic invertebrate assemblages of large rivers contained several rare or remarkable species, especially among stoneflies, e.g., Marthamea vitripennis, Xanthoperla apicalis. We compared benthic invertebrate communities in river sections with fine and coarse substrates and in three eco-hydromorphological (ECO-HM) types of large rivers, reflecting habitat heterogeneity: lowland-deep, lowland-braided and intermountain. Multivariate analysis of variance (PERMANOVA) was used to statistically evaluate similarities among assemblages. It was found that the composition of benthic invertebrate assemblages varied by both ECO-HM types and substrate category. Similarity percentage (SIMPER) analysis showed that the average dissimilarity of benthic invertebrate assemblages was high between all ECO-HM type pairs and between fine and coarse substrate. We found that habitat heterogeneity and substrate independently influenced benthic invertebrate assemblages. To achieve ecological goals in the management of large rivers, in addition to functionality, a holistic view with at least near-natural assemblages, including the names of the taxa present, should also be considered.
\end{abstract}

Keywords: large rivers; reference conditions; near-natural conditions; eco-hydromorphological types; substrate; river-basin management; WFD; southeast Europe

\section{Introduction}

Large rivers provide a plethora of utilities for humankind, such as a source of water for domestic, industrial and agricultural purposes, a means of energy production and waste disposal, routes for navigation, and space for recreational activities [1]. However, these human uses are also pressures and, in combination with land use changes in their catchments, pose a threat to the function and ecological integrity of aquatic ecosystems. The long history of intensive use of large rivers has led to the degradation of unique ecosystems, and today large rivers are among the most degraded ecosystems on Earth. Concerns about the ecological quality of aquatic habitats have led to legislation in most developed countries that sets the objectives (e.g., EU Water Framework Directive 2000, US 
Clean Water Act of 1972, Australian Water Reform Framework [2]). The European Union in its Water Framework Directive set 2015 as the year by which good ecological status should also be achieved for rivers [3], though these aspirations are yet to be achieved, due primarily to hydromorphological alterations that were identified as the main reason for water bodies being unable to achieve the environmental objectives of Water Framework Directive [4]. The European Green Deal was developed and published at the EU level [5] as a holistic document that aims to improve the wellbeing and health of citizens and future generations. It contains a proposal for legally binding EU nature conservation targets for restoring degraded ecosystems in the framework of the EU Biodiversity Strategy by 2030 [6]. The importance of "semi-natural" rivers was recognized through the restoration of river continuity and reinforced by a target to transform at least $25,000 \mathrm{~km}$ of rivers into free-flowing rivers by 2030, mainly through the removal of obsolete barriers and restoring floodplains and wetlands. In addition, according to the strategy, Member State authorities are also required to review water abstraction and impoundment permits with the aim of restoring ecological flows.

Due to the understanding that altering the hydrology, water chemistry and biology of rivers has unintended consequences on human lives, an increasing number of restoration projects were initiated [7-10]. A prevailing paradigm in ecological restoration is that increasing habitat heterogeneity promotes biodiversity restoration, which is reflected in stream restoration projects through the common practice of reconfiguring channels by adding meanders and physical structures. A scientific review of river restoration projects found that most projects successfully improved physical habitat heterogeneity, though very few showed a statistically significant increase in biodiversity, increasing their similarity to reference reaches or sites [11]. Improved ecological conditions are a true measure of river restoration success, where observed conditions should be compared to reference conditions. The reference conditions approach, which implies past historical conditions, is widely used in ecological assessment and current legislation now widely depends on the establishment of reference standards (e.g., Water Framework Directive). In Europe, type-specific reference conditions have been established in a variety of ways, often taking a pragmatic approach [12]. The latter is particularly true when sites with at least nearnatural conditions are lacking, as is the case for most large rivers in the EU. Regardless of whether reference conditions are based on true reference sites or near-natural sites, their selection is crucial for the development of useful measures of ecological status [13]. The characteristics of biota occurring at reference sites are used to develop metrics and indices that serve as a basis for comparison with impacted sites of the same river-type to assess their ecological status. Therefore, biota representing reference conditions are a key element of river ecological assessment, restoration and sustainable river basin management. The key question is whether reference sites or at least near-natural sites are available for large rivers and what the differences are in the biota between large river types.

In Europe, river engineering began several centuries ago, and today most European large rivers are channelized and highly fragmented by dams, with few catchments still containing free-flowing large rivers [14]. In large rivers, human impact often increases along the river course, i.e., the lower reaches are the most disturbed $[15,16]$. The Dinaric Western Balkan and the Pannonian Lowland (Ecoregions 5 and 11) $[17,18]$ are areas in Europe where free-flowing large rivers still exist. According to water quality results, the impact of pollution is relatively low (e.g., $[19,20]$ ); thus, near-natural large river stretches can still be found. The Kupa and Una are in near-natural conditions along their river courses. The Drava is one of the few rivers in Europe that is not regulated in its middle and lower sections. The lower Drava in Hungary has been protected as a national park since 1996 [21]. Large parts of the Sava River still show a relatively natural geomorphic structure and hydrological regime, lined by large, protected wetlands. The mainstream has been channelized for flood control only in a few, short sections (e.g., in Zagreb); the mainstream has been channelized for flood control [14]. There are two Ramsar sites and three Important Bird Areas [22] in the middle reaches of the Sava, and this river is a priority area in the Pan 
European Biodiversity and Landscape Strategy programmes and a key site in the Danube River Basin programmes. The Sava, the lower Drava, Mura and Kupa also have significant floodplains. A good example of intact floodplains is the Lonjsko Polje Nature Park on the Sava [23]. However, these types of habitats are becoming increasingly rare as development fundamentally changes river courses and floodplain landscapes. Although all these rivers are located in the same region, certain sections differ in their natural habitat heterogeneity, which is reflected in the eco-hydromorphological types $[19,20]$.

The aims of this study were (i) to define near-natural benthic invertebrate assemblages of large rivers, (ii) to examine difference in benthic invertebrate assemblage compositions between three eco-hydromorphological types of large rivers; lowland-deep, lowland-braided and intermountain and (iii) to explain some of the key drivers of benthic invertebrate variation across these river types. We hypothesized that (i) the composition of near-natural benthic invertebrate assemblages and contribution of taxa vary among large river types, and (ii) substrate and habitat heterogeneity independently influence the composition of benthic invertebrate assemblages.

\section{Materials and Methods}

\subsection{Study Area}

The study was conducted in two neighbouring countries: Slovenia with a total area of $20,273 \mathrm{~km}^{2}$ and Croatia with a total area of $56,594 \mathrm{~km}^{2}$. The rivers in each of these countries flow into either the Danube Basin or Adriatic Basin, but this study focused only on the Danube catchment, covering $16,381 \mathrm{~km}^{2}(80.8 \%)$ of the Slovenian territory and $35,101 \mathrm{~km}^{2}(62 \%)$ of the Croatian territory. This study was limited to five major rivers of the Danube Basin: Drava, Mura, Sava, Kupa and Una Rivers. Only stretches with a catchment area of 5000 to $64,000 \mathrm{~km}^{2}$ at altitudes between 74 and $338 \mathrm{~m}$ were considered. These stretches belong to three eco-hydromorphological types $[19,20]$ : intermountain, lowland-braided and lowland-deep (Table 1, Figure 1). The Sava and Drava are among the largest tributaries of the Danube River (first and fourth, respectively) and represent some of the most preserved rivers in Europe in terms of their biological and landscape diversity. Nature conservationists and scientists consider the Sava to be one of the "crown jewels" of European nature [24]. The lower Drava, together with the lower Mura, forms a $380 \mathrm{~km}$ long, free-flowing and relatively natural watercourse, representing one of the last remaining contiguous riverine landscapes in Central Europe [23].

Table 1. Main characteristics of the sampled rivers according to the eco-hydromorphological river type and the number of sampling sites and samples.

\begin{tabular}{clrrr}
\hline \multirow{2}{*}{ River } & Eco-Hydromorphological & $\begin{array}{r}\text { Catchment Size Range } \\
\text { Type }\end{array}$ & Altitude Range (m a.s.l.) & No. Sites (Samples) \\
\hline Sava & Intermountain & $4946-5203$ & $191-222$ & $3(7)$ \\
Drava & Lowland-braided & $13,189-31,038$ & $122-236$ & $7(11)$ \\
Mura & Lowland-braided & $9784-10,930$ & $153-246$ & $6(12)$ \\
Sava & Lowland-deep & $7151-64,073$ & $74-191$ & $7(8)$ \\
Drava & Lowland-deep & $33,916-39,982$ & $81-100$ & $3(3)$ \\
Kupa & Lowland-deep & $9184-9184$ & $92-92$ & $1(2)$ \\
Una & Lowland-deep & $9368-9368$ & $94-94$ & $1(2)$ \\
\hline
\end{tabular}




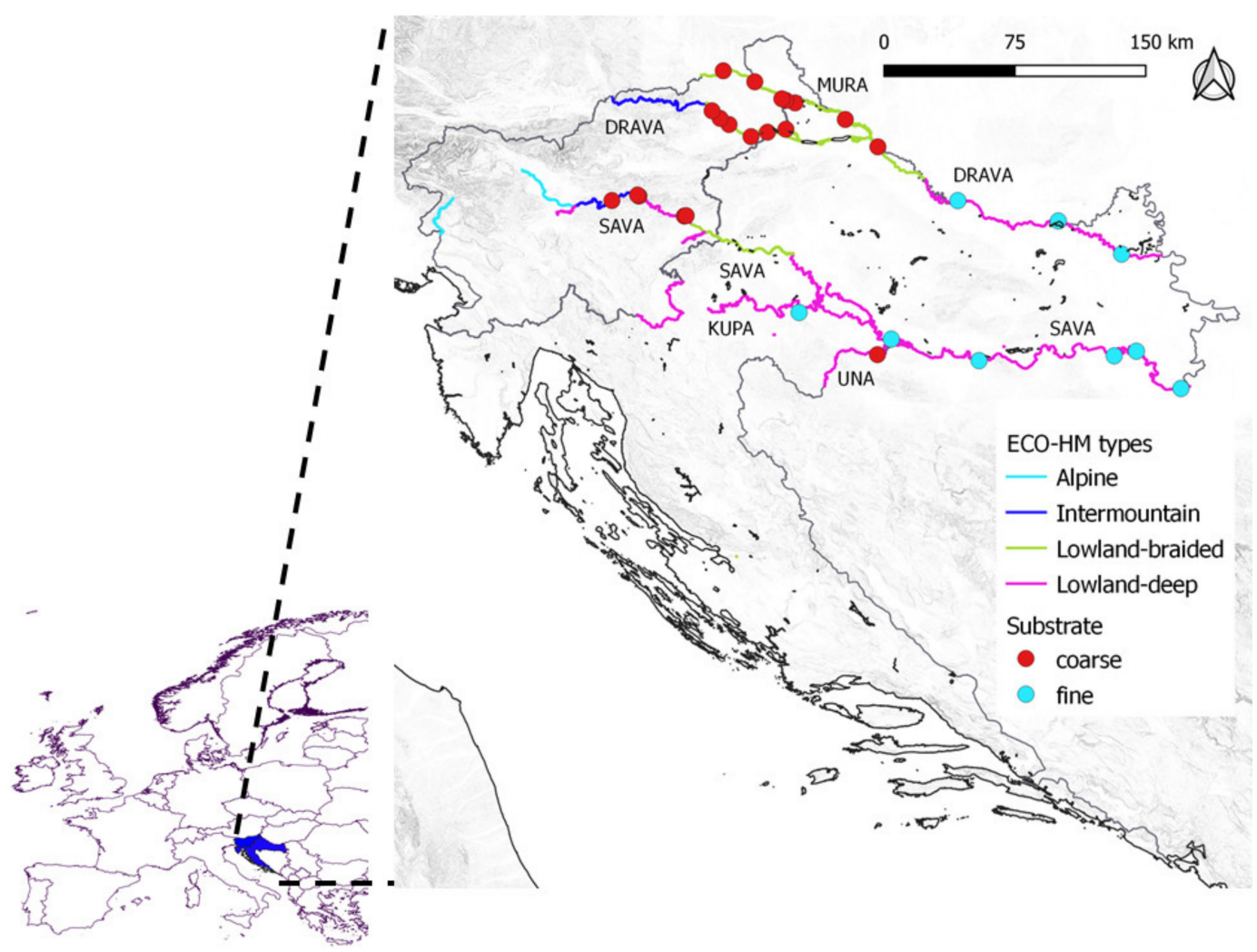

Figure 1. Study area with large river eco-hydromorphological (ECO-HM) types and near-natural sampling sites with prevailing natural substrate (closed circles).

\subsection{Environmental Variables}

The 28 sampling sites (Figure 1) selected cover "near-natural conditions", reflecting no or slight disturbance levels caused by hydromorphological alteration, water quality, catchment land-use and alien species (Table 2). Some variables were used as exclusion criteria for selection of suitable samples, or simply to represent values recorded at "nearnatural" sites. The following criteria related to hydromorphology $[19,25]$, water quality conditions [19,26-29], Corine land use/land cover [30] and alien species were used to select these near-natural sites:

(a) Hydromorphological quality and assessment index (HQM), reflecting the combined influence of habitat quality, habitat modifications and upstream and/or downstream barriers: $\mathrm{HQM}>0.6$ (at least class 2).

(b) Hydrological modification index (HLM) reflecting influence of upstream/downstream barriers (impoundments): HLM > 0.6 (at least class 2).

(c) Saprobic index (minimum normalised value-ecological quality ratio (EQR) for the Slovenian (SIG3) and Croatian version (SIHR): EQR > 0.6 (at least good ecological status).

(d) Percentage of CLC natural and semi-natural land use/land cover in the catchment at least 50\% and CLC intensive agriculture + urban land use/land cover in the catchment $<30 \%$, where CLC urban land use/land cover in the catchment $<5 \%$.

(e) Alien species could be present but account for $<35 \%$ of the benthic invertebrate assemblage. 
Table 2. Median, minimum and maximum values of the selected hydromorphology, water quality, land use variables and proportion of alien species at near-natural sites.

\begin{tabular}{|c|c|c|c|}
\hline Variable & Median & Minimum & Maximum \\
\hline Low annual discharge $\left(\mathrm{m}^{3} / \mathrm{s}\right)$ & 99 & 7 & 648 \\
\hline Mean annual discharge $\left(\mathrm{m}^{3} / \mathrm{s}\right)$ & 140 & 9 & 998 \\
\hline High annual discharge $\left(\mathrm{m}^{3} / \mathrm{s}\right)$ & 399 & 90 & 1530 \\
\hline Hydromorphological quality and modification index (HQM) & 0.84 & 0.71 & 1 \\
\hline Hydrological modification index (HLM) & 0.94 & 0.68 & 1 \\
\hline Water temperature-median $\left({ }^{\circ} \mathrm{C}\right)$ & 12.0 & 9.8 & 16.1 \\
\hline $\mathrm{pH}-$ median & 8.0 & 7.7 & 8.3 \\
\hline Conductivity-median $(\mu \mathrm{S} / \mathrm{cm})$ & 350 & 299 & 480 \\
\hline Total suspended solids-median (mg/L) & 7 & 3 & 56 \\
\hline Total nitrogen-median $(\mathrm{mgN} / \mathrm{L})$ & 1.60 & 0.69 & 2.34 \\
\hline Ammonium-median (mgN/L) & 0.06 & 0.01 & 0.30 \\
\hline Nitrate-median $(\mathrm{mgN} / \mathrm{L})$ & 1.40 & 0.50 & 2.01 \\
\hline Orthophosphate-median (mgP/L) & 0.05 & 0.01 & 0.29 \\
\hline Biochemical oxygen demand (5 days) —median (mg/L) & 1.2 & 0.8 & 2.4 \\
\hline Chemical oxygen demand $\left(\mathrm{K}_{2} \mathrm{Cr}_{2} \mathrm{O}_{7}\right)$-median $(\mathrm{mg} / \mathrm{L})$ & 6.15 & 2.5 & 19.6 \\
\hline Oxygen concentration-median $(\mathrm{mg} / \mathrm{L})$ & 9.55 & 8.55 & 11.5 \\
\hline Oxygen saturation-median $(\mathrm{mg} / \mathrm{L})$ & 90 & 80 & 104 \\
\hline Saprobic index (EQR) & 0.78 & 0.63 & 1.00 \\
\hline CLC Natural $(\%)$ & 71 & 55 & 78 \\
\hline CLC Agriculture (\%) & 25 & 19 & 43 \\
\hline CLC Intensive agriculture (\%) & 12 & 8 & 26 \\
\hline CLC Extensive agriculture (\%) & 12 & 11 & 25 \\
\hline CLC Urban $(\%)$ & 4 & 1 & 5 \\
\hline Alien species (\%) & 0 & 0 & 33.3 \\
\hline
\end{tabular}

Twenty-four environmental variables were measured or calculated: five hydromorphological, fourteen water quality, and five catchment land cover/land use variables. Details of how the variables were obtained or calculated are described elsewhere [20]; only a summary is provided here. Water flow data were obtained from available discharge data from the hydrological databases of the Slovenian Environment Agency (ARSO) and Croatian Meteorological and Hydrological Service (DHMZ). The mean daily discharges were used to calculate the mean annual discharge (MQ), the lowest annual discharge (daily mean, NQ) and the highest annual discharge (daily mean, HQ) of the sampling year. The Slovenian hydromorphological (SIHM) assessment method $[19,25,31]$ was applied to examine habitat quality, habitat modifications and the influence of the main upstream barriers/impoundments. A river habitat survey [32,33] was conducted once between 2005 and 2012 in the benthic invertebrate sampling year or after sampling for each sampling site and the data were used to calculate the two morphological indices [25,31]: river habitat quality index (RHQ), and river habitat modification index (RHM). Normalised values (converted to a common scale of $0-1$; RHQnor and RHMnor [19]) were used according to the eco-hydromorphological type of the considered river stretches according to Urbanič and Urbanič et al. [32,33] (Table 1, Figure 1). The data on impoundments recorded in the catchment of each sampling site in the year of benthic invertebrate sampling were used to calculate the hydrological modification index (HLM, $[19,25])$. The combination of the RHQnor, RHMnor and HLM indices was used to calculate the hydromorphological quality and modification index (HQM) $[19,25,31]$. Physical and chemical data were obtained monthly or at least four times per year (each season) from national surface water monitoring programmes during the sampling year. Only selected water quality parameters were used that were available for all selected sites: water temperature, conductivity, $\mathrm{pH}$, oxygen concentration, oxygen saturation, water temperature, chemical oxygen demand $\left(\mathrm{K}_{2} \mathrm{Cr}_{2} \mathrm{O}_{7}\right)$, biochemical oxygen demand $\left(\mathrm{BOD}_{5}\right)$, orthophosphate, total nitrogen, ammonium and total suspended solids. The ecological quality ratio values were calculated based on the saprobic index according to the national standards [26-29]. The median of data collected for each parameter in the 
benthic invertebrate sampling year is shown in Table 2. In addition to the variables listed, for each site the naturally predominant substrate of each site was classified into two classes: fine (psammal) or coarse (lithal). The information on eco-hydromorphological river type was based on previous studies $[19,20]$. Land use variables were based on the proportion of land use categories at the catchment scale, extracted from Corine land cover (CLC) data [30] using ArcGIS version 10.2.1 (Esri Corp., Redlands, CA, USA). The categories were grouped into five land use variables: urban land use (CLC class 1), natural and semi-natural land use (CLC classes 3-5), extensive agricultural land use (CLC categories 2.3.1, 2.4.3, 2.4.4), and intensive agricultural land use (CLC categories 2.1, 2.2, 2.4.1, 2.4.2).

\subsection{Benthic Invertebrates}

Biological data were obtained as part of the WFD monitoring and assessment system development programmes in Slovenia and Croatia between 2005 and 2011. A total of 104 samples were collected at 56 sites [20], and of these 45 samples at 28 sampling sites met the criteria for "near-natural sites" as used in this study. Most samples (13) were collected in the lowland-braided sections of the Drava and Mura Rivers, 12 samples in the lowland-deep sections of the Sava, Drava, Kupa and Una Rivers, and seven samples were collected in the intermountain sections of the Sava River (Table 1). Some sites were sampled several times, but not more than once per year. Benthic invertebrates were collected at low to moderate flows using a multihabitat sampling approach. A detailed description of benthic invertebrate sampling is provided elsewhere $[19,20]$. Samples were collected in the wadeable part of the main channel using a hand net (frame $25 \times 25 \mathrm{~cm}$, mesh-size: $500 \mu \mathrm{m}$ ). Twenty subsamples were collected at each site with a total sampling area of $1.25 \mathrm{~m}^{2}$ along a 100-250 m river stretch. The sampling procedure in Slovenia followed the standardized Slovenian river bioassessment protocol and is described in detail elsewhere $[19,34,35]$. Twenty sampling units were selected in proportion to the coverage of microhabitat types. Microhabitat types were defined as a combination of substrate and flow type with coverage of at least $5 \%$. The channel substrates of each sampling site were classified according to [36], while the flow characteristics were classified according to [19,35,37]. Sampling units were pooled, preserved in the field with $96 \%$ ethanol and transported to the laboratory for further processing. Each sample was subsampled, and benthic organisms from one quarter of the total field sample were identified and counted. In Croatia, samples were collected according to the AQEM sampling strategy [36]. A total of 20 sampling units from representative substrates (i.e., substrates with a coverage $>5 \%$ in the sampled reach) were sampled. In 2009, 10 subsampling units were collected from sampling sites (five sites) with homogenous substrates (sand and other soft sediments). In these cases, the sample was collected by pushing the hand net through the top $(2-5 \mathrm{~cm})$ layer of the substrate. Sampling units were pooled, preserved in the field with $96 \%$ ethanol and transported to the laboratory for further processing. In 2006, a more elaborate subsampling design was used: habitat (substrate)-specific subsampling units were pooled and analysed as separate samples. At least one-sixth of the sample was sorted in the laboratory until the target minimum number of 500 (habitat-specific samples) or 700 individuals (multihabitat samples) was reached. Benthic invertebrates were generally identified to the species and genus level but Oligochaeta and Diptera were identified to the (sub)family and genus level (Appendix A).

\subsection{Data Analyses}

Variation in composition and structure of benthic invertebrate data were analysed using the Bray-Curtis similarity measure. Assemblage similarities were then visualized by nonmetric multidimensional scaling (NMS) plots, and statistically evaluated via permutational multivariate analysis of variance (PERMANOVA, [38]). In NMS plots, the samples vicinity to other samples in portrayable space-typically two dimensions-reflects their underlying similarity in multivariate space, and accordingly, this is the preferred method for illustrating relationships among ecological communities [39,40]. PERMANOVA 
is a multivariate, nonparametric permutation test for assessing differences in community composition or structure between two or more predefined treatment groups (ecohydromorphological river types). We used a two-way PERMANOVA to test for significant structural differences between the benthic invertebrate assemblages of (a) the three eco-hydromorphological river types, and (b) the two substrate categories. When differences in benthic invertebrate assemblage structure were detected between the ecohydromorphological river types and the substrate categories, similarity percentage (SIMPER) analyses were conducted to determine the contribution of specific taxa to these differences. The benthic invertebrate abundances were $\ln (y+1)$ transformed prior to analysis. All statistical and graphical analyses were performed using the PAST data analysis package (v 3.14), (Natural History Museum, Oslo, Norway) [41].

\section{Results}

A total of 268,471 individuals representing 229 benthic invertebrate taxa were collected in 45 samples (Appendix A). Most of the taxa collected were autochthonous, but nine alien species were also recorded. Alien species were recorded in 16 benthic samples. Most alien species were detected in one to six samples (Dugesia tigrina, Branchiura sowerbyi, Potamopyrgus antipodarum, Sinanodonta woodiana, Corbicula fluminea, Dikerogammarus villosus, Dikerogammarus haemobaphes and Jaera istri), but Chelicorophium curvispinum was found in 11 samples. The recorded taxa included several species, e.g., the stonefly Marthamea vitripennis and Xanthoperla apicalis. Marthamea vitripennis was recorded in the Una River, while Xanthoperla apicalis was found in the Mura and Drava Rivers. Other large stonefly species from the Perlidae family were also recorded, e.g., Dinocras cephalotes and Perla abdominalis (P. burmeisteriana) in the Mura and Una Rivers. Several caddisfly species typical of large rivers were recorded: Hydropsyche bulgaromanorum in the Drava and Sava rivers, $H$. ornatula in the Sava, H. modesta in the Mura, Drava and Sava rivers, H. contubernalis was present in all five rivers, and Setodes punctatus in the Drava, Kupa and Una rivers.

Site grouping in the NMS showed that the benthic invertebrate assemblages differ among substrates (Figure 2A). The site grouping of eco-hydromorphological river types was distinct, but less clear, especially between intermountain and lowland-braided rivers (Figure 2B). PERMANOVA confirmed significant differences in assemblage structure between coarse and fine substrates $\left(\mathrm{F}=4.62, \mathrm{R}^{2}=0.19, p<0.0001\right)$ and among ECO-HM types, where a slightly higher explanatory power was observed $\left(\mathrm{F}=4.62, \mathrm{R}^{2}=0.22, p<0.0001\right)$. Despite the observed overlap of intermountain and braided samples in the NMS diagram, PERMANOVA revealed differences in assemblage composition between all pairs of ECOHM types $(\mathrm{F}=3.67-7.85, p=<0.0001-0.0003)$. The interaction between ECO-HM types and substrates was not significant $(p>0.05)$ (Table 3$)$.

Similarity percentage (SIMPER) analysis indicated that the overall average dissimilarity of benthic invertebrate assemblages of all eco-HM type pairs was $>50$, with the highest dissimilarity between lowland-braided and lowland-deep rivers (69.21) and the lowest dissimilarity between intermountain and lowland-braided rivers (54.59). Gammarus fossarum, Nais sp., Orthocladiinae, Stylodrilus heringianus, Lithoglyphus naticoides, Hydropsyche incognita, Tubificidae (with and without hair chaetae), Heptagenia sulphurea, Baetis rhodani, Hydropsyche sp.-juv. and Gammarus roeseli were largely responsible for the observed differences among benthic invertebrate assemblages (Table 4). However, Nais sp. was the only taxon that was among the ten most influential taxa contributing to the observed differences between benthic invertebrate assemblages of all pairs of ECO-HM types. These taxa were also largely responsible for the observed differences between benthic invertebrate assemblages of coarse and fine substrates (Table 5), confirming that some differences between assemblages of ECO-HM types were also due to substrate differences. Most taxa with the highest percentage contribution to differences between coarse and fine substrates were found in higher abundance in rivers with coarse substrates, e.g., Gammarus fossarum, Orhocladiinae, Stylodrilus heringianus, Nais sp., Hydropsyche sp.-juv, Baetis rhodani, Psycomyiia pusilla and Hydropsyche incognita. The latter two species were not found in rivers 
with fine substrate. On the other hand, Lithoglyphus naticoides and Tubificidae without hair chaetae preferred river sections with fine substrate.
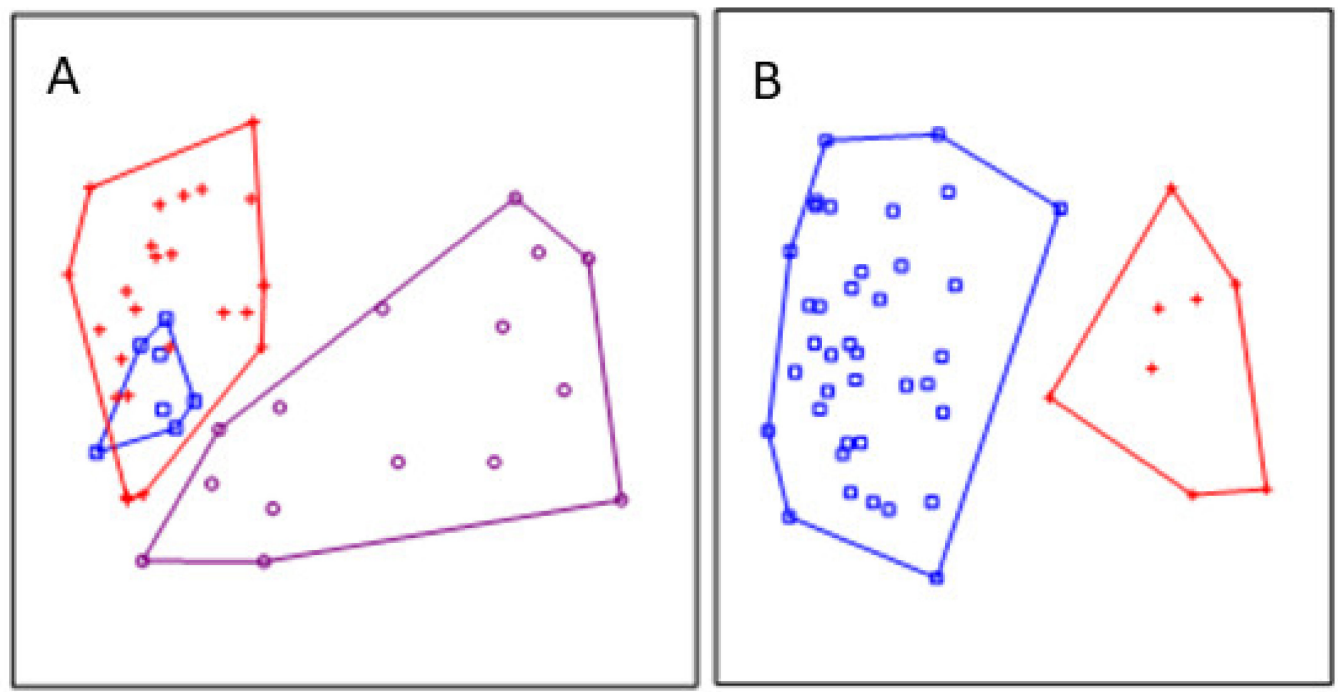

Figure 2. Nonmetric multidimensional scaling ordination diagrams of sampling sites. (A) Overlay indicates eco-hydromorphological types: intermountain $(\square)$, lowland-braided (+), lowland-deep (o). (B) Overlay indicates coarse $(\square)$ and fine $(+)$ substrate. Stress (two-dimensional space) $=0.19$.

Table 3. PERMANOVA test of eco-hydromorphological types of large rivers and substrates and their interactions. ECO-HM-eco-hydromorphological river type, Df-degrees of freedom, $p$ - probability of statistical significance based on 9999 permutations of the data.

\begin{tabular}{ccccccc}
\hline Scheme 2. & Df & Sum of Sqrs & Mean Square & $\mathbf{F}$ & $\mathbf{R}^{\mathbf{2}}$ & $\boldsymbol{p}$ \\
\hline ECO-HM type & 2 & 2.22 & 1.11 & 2.64 & 0.22 & 0.0001 \\
Substrate & 1 & 1.94 & 1.94 & 4.62 & 0.19 & 0.0001 \\
Interaction & 2 & -10.78 & -5.39 & -12.83 & & 1 \\
Residual & 40 & 16.81 & 0.42 & & & \\
Total & 45 & 10.18 & & & & \\
\hline
\end{tabular}




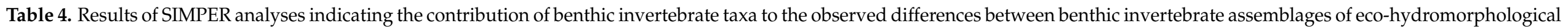

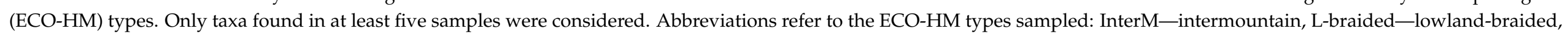
L-deep-lowland-deep. For taxon abbreviations, see Appendix A.

\begin{tabular}{|c|c|c|c|c|c|c|}
\hline ECO-HM Type A vs. B & $\begin{array}{c}\text { Overall Average } \\
\text { Dissimilarity }\end{array}$ & $\begin{array}{c}\text { Ten Most } \\
\text { Influential Taxa }\end{array}$ & $\begin{array}{c}\text { Percent Contibution to } \\
\text { Difference }\end{array}$ & $\begin{array}{c}\text { Cumulative Percent } \\
\text { Contibution to Difference }\end{array}$ & $\begin{array}{l}\text { Average abundance } \\
\text { (log10)-Type A }\end{array}$ & $\begin{array}{l}\text { Average Abundance } \\
\text { (log10)-Type B }\end{array}$ \\
\hline \multirow[t]{8}{*}{ InterM vs. L-braided } & 54.59 & Nai_sp. & 3.2 & 3.2 & 1.10 & 1.65 \\
\hline & & The_dan & 2.9 & 6.1 & 1.32 & 0 \\
\hline & & Hyd_inc & 2.7 & 11.5 & 1.95 & 0.97 \\
\hline & & Gam_roe & 2.6 & 14.1 & 0 & 1.25 \\
\hline & & Hep_sul & 2.6 & 16.7 & 0 & 1.18 \\
\hline & & Sim_sp. & 2.5 & 19.2 & 1.38 & 0.78 \\
\hline & & Eis_tet & 2.4 & 24.1 & 1.18 & 0.39 \\
\hline & & Tubb_dae & 2.3 & 26.4 & 0.96 & 1.68 \\
\hline \multirow{9}{*}{ InterM vs. L-deep } & 66.15 & Gam_fos & 5.4 & 5.4 & 3.20 & 0.85 \\
\hline & & Hyd_inc & 3.8 & 9.1 & 1.95 & 0.26 \\
\hline & & Lith_nat & 3.2 & 12.4 & 0 & 1.39 \\
\hline & & Hyd_spj & 3.1 & 15.4 & 1.97 & 0.62 \\
\hline & & Psy_pus & 3.1 & 18.5 & 1.80 & 0.54 \\
\hline & & Orth_nae & 2.9 & 21.4 & 2.46 & 1.67 \\
\hline & & Bae_rho & 2.8 & 24.2 & 1.57 & 0.69 \\
\hline & & Ant_sp. & 2.7 & 29.7 & 1.39 & 0.15 \\
\hline & & Nai_sp. & 2.5 & 32.2 & 1.10 & 0.41 \\
\hline \multirow[t]{10}{*}{ L-braided vs. L-deep } & 69.21 & Gam_fos & 5.4 & 5.4 & 3.12 & 0.85 \\
\hline & & Lith_nat & 3.3 & 8.7 & 0.03 & 1.39 \\
\hline & & Orth_nae & 3.3 & 11.9 & 2.62 & 1.67 \\
\hline & & Nai_sp. & 3.2 & 15.1 & 1.65 & 0.41 \\
\hline & & Sto_her & 2.8 & 17.9 & 1.63 & 0.98 \\
\hline & & Gam_roe & 2.4 & 20.3 & 1.25 & 0.13 \\
\hline & & Tubb_dae & 2.4 & 22.7 & 1.68 & 1.77 \\
\hline & & Hep_sul & 2.3 & 25.1 & 1.18 & 0.55 \\
\hline & & Bae_rho & 2.2 & 27.3 & 1.02 & 0.69 \\
\hline & & Tubz_dae & 2.2 & 29.5 & 0.75 & 1.13 \\
\hline
\end{tabular}




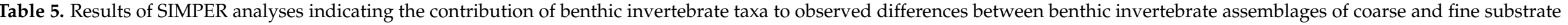
types. Only taxa found in at least five samples were considered. For taxon abbreviations, see Appendix A.

\begin{tabular}{|c|c|c|c|c|c|c|}
\hline Substratum & $\begin{array}{l}\text { Overall Average } \\
\text { Dissimilarity }\end{array}$ & $\begin{array}{c}\text { Ten Most } \\
\text { Influential Taxa }\end{array}$ & $\begin{array}{c}\text { Percent Contibution to } \\
\text { Difference }\end{array}$ & $\begin{array}{c}\text { Cumulative Percent } \\
\text { Contibution to Difference }\end{array}$ & $\begin{array}{l}\text { Average Abundance } \\
(\log 10)-\text { Coarse }\end{array}$ & $\begin{array}{l}\text { Average Abundance } \\
(\log 10) \text {-Fine }\end{array}$ \\
\hline \multirow[t]{8}{*}{ Coarse vs. fine } & 74.91 & Gam_fos & 6.4 & 6.4 & 2.88 & 0.08 \\
\hline & & Orth_nae & 4.6 & 11.0 & 2.63 & 0.68 \\
\hline & & Sto_her & 3.3 & 18.9 & 1.65 & 0.22 \\
\hline & & Nai_sp. & 2.8 & 21.7 & 1.33 & 0.36 \\
\hline & & Psy_pus & 2.7 & 24.4 & 1.29 & 0 \\
\hline & & Tubb_dae & 2.5 & 26.9 & 1.48 & 2.19 \\
\hline & & Bae_rho & 2.4 & 31.8 & 1.13 & 0.36 \\
\hline & & Hyd_inc & 2.3 & 34.1 & 1.07 & 0 \\
\hline
\end{tabular}




\section{Discussion}

The selection of reference or near-natural sites and description of reference communities should be based on criteria associated with human disturbances that affect aquatic assemblages at a level of no or low impact. We chose stressors of different spatial scales describing different aspects of the aquatic environment (water quality, hydromorphology, land use in the catchment, alien species) that have been shown to be critical in shaping benthic invertebrate assemblages in large rivers $[19,20]$. Usually, the stressors applied in studies are a simplification of the true stressors to which biota are exposed. In this study, we performed river habitat surveys (RHS) once, which could bias the results because habitat condition changes over time. The hydromorphological quality and modification (HQM) index used in this study is partly based on the RHS conducted once in a given period. However, it proved to be very robust to natural change as it is based not only on river habitat survey data, but also on the presence of upstream and downstream impoundments considered in the year of benthos sampling. Environmental conditions in large rivers generally deteriorate over time and rarely improve (e.g., through restoration); thus, conducting RHS surveys after benthos sampling should not be an issue. We dealt with near-natural sites and all parameters were used as knockout criteria. In the case that habitat condition deteriorated prior to RHS was conducted, such sites would not be considered.

Reference conditions are not only commonly used for ecological assessment, but are also important for restoration and river management in general, as improvement in ecological conditions is a true measure of management success. However, it can be difficult to find sites with at least near-natural conditions, as is the case with most large rivers in the EU. Southeast Europe still has stretches of large rivers with near-natural conditions where some rare benthic invertebrate taxa occur, as confirmed here. Marthamea vitripennis, rediscovered after 100 years in the Una River [42], once occurred in the rivers of central and southeast Europe, but is now largely extinct [43]. Xanthoperla apicalis, another stonefly species that is a potamal species, at least in central Europe, had disappeared for decades and was only recently rediscovered [43]. Other detected large stonefly species from the family Perlidae (Dinocras cephalotes and Perla abdominalis in the Mura and Una Rivers, respectively) confirm that remarkable large insect species can also occur in near-natural conditions of large rivers, playing an important role in the functioning of large rivers. We also found some other less endangered but typical potamal species typical for larger rivers, e.g., the caddisfly Hydropsyche bulgaromanorum, which still occurs in the lower Sava and the lower Drava. This was a common and dominant Hydropsyche species farther upstream (in the middle Drava near Maribor, Slovenia), prior to the construction of hydroelectric power plants, but it no longer occurs today (Urbanič, unpublished data). In addition to rare and typical potamal species, alien species are becoming increasingly common in near-natural sections of large rivers [44]. In the present study, we excluded sites dominated by alien species. However, in the near future, alien species might dominate river stretches with nearnatural conditions, especially due to artificial connections between river catchments [45,46]. Most alien species recorded in this study are Ponto-Caspian elements that have spread upstream.

In the EU, type-specific reference conditions have often been established in the spirit of national individuality and with a distinct lack of stringency in defining reference states [47,48]. It is well known that river degradation leads to the homogenisation of aquatic communities [49]. Therefore, the use of communities from degraded sites could lead to a reduced number of taxa in reference communities, lower ecological expectations and a smaller number of recognised distinct river types. Abiotic factors, particularly hydromorphological characteristics, are often used for river typologies, which may lead to a lower number of river types [50] compared to the number of ecological river types. In Slovenia, a much smaller number of hydromorphological types compared to ecological types were recognised, although habitat diversity was taken into account. This is especially true for small rivers [25,34] and to a lesser extent for large rivers [19]. In the present study, the benthic invertebrate community composition differed significantly in all three 
eco-hydromorphological types that were considered for large rivers. This is even more remarkable because not all taxa were determined to species level. Nevertheless, Nais sp. was the only taxon that was among the ten most influential taxa contributing to the observed differences between the benthic invertebrate assemblages of all pairs of ECO-HM types. Thus, it is evident that not only the taxonomic composition but also the abundance of taxa differs between ECO-HM types. Habitat heterogeneity is important from the biodiversity point of view and was considered when delineating the eco-hydromorphological large river types [19]. However, the eco-hydromorphological types considered differ not only in habitat heterogeneity, but also in water depth associated with flow type and substrate size. We identified the latter as one of the key factors defining the benthic invertebrate communities of large rivers, as in many studies (see [51]). There were several taxa that preferred river types with coarse substrates, while some, such as the snail Lythoglyphus naticoides and Tubificidae without hair chaetae, preferred rivers with fine substrates. This is consistent with the finding that rivers with coarse substrates harbour more diverse communities compared to rivers with fine substrates [52].

A pragmatic approach has often been taken in setting reference conditions in the EU [12]. It has often been stated that reference conditions or near-natural conditions are also lacking in the case of most large river types in the EU. We have shown here that large rivers with near-natural conditions still exist or existed recently, and provide a description of the type-specific near-natural benthic invertebrate communities. Therefore, it might be possible to set ecological conditions that would serve as a true measure of assessment river restoration success and river management, especially in line with the EU Water Framework Directive. Following this pragmatic approach, the European Green Deal has set the restoration targets for rivers at EU level based only on the length of stretches that have been transformed back into free-flowing rivers by removing mainly obsolete barriers. Addressing one of the main pressures [4,53] could be a good starting point for river restoration. Parameters related to barriers have also been shown to be key factors for benthic invertebrate community composition and ecological status [19], together with fish composition in large rivers [54]. Fish communities may show a rapid response to dam removal [55]. However, although restoration is needed as river degradation is ongoing in Europe, it is evident that large rivers are affected by multiple stressors $[4,35,56,57]$. For benthic invertebrate assemblages in southeast European large rivers, water quality and land use effects are almost equally important as hydromorphological conditions [20], indicating that considering hydromorphological conditions alone in restoration may be insufficient. A more holistic view of restoration may be required to achieve ecological goals [58], particularly where the names of taxa present (reference communities) are important in addition to functionality.

\section{Conclusions}

Reference conditions, or at least near-natural conditions, are not only commonly used for ecological assessment, but are also important for restoration and river management, as improvement in ecological conditions is a true measure of management success. In most large rivers in the EU, it can be difficult to find sites with at least near-natural conditions, though southeast Europe still has stretches of large rivers with near-natural conditions where some typical potamal and rare benthic invertebrate taxa occur. We defined the near-natural benthic invertebrate assemblages of large rivers containing several rare and remarkable species among the stoneflies, e.g., Marthamea vitripennis, Xanthoperla apicalis, Dinocras cephalotes, Perla abdominalis (P. burmeisteriana). We compared the composition of benthic invertebrate assemblages among three eco-hydromorphological (ECO-HM) types of large rivers (lowland-deep, lowland-braided and intermountain) and found that the composition of near-natural benthic invertebrate assemblages varied among large river types. Overall, the average dissimilarity in assemblage composition among all ECO-HM type pairs was high, with the highest dissimilarity between lowland-braided and lowlanddeep rivers, and the lowest dissimilarity between intermountain and lowland-braided 
rivers. ECO-HM large river types were defined based on habitat heterogeneity, but also differed in water depth associated with flow type and substrate size. We found that habitat heterogeneity and substrate independently influence the composition of the benthic invertebrate assemblages. Habitat heterogeneity is often generally considered in river assessment, restoration projects or river management. However, it is evident that other factors should also be considered to maintain or restore ecological conditions with relevant benthic communities. For example, simple restoration goals for rivers, such as the length of stretches restored to free-flowing rivers, as stated in the European Green Deal, may not ensure sufficiency to meet all ecological objectives. To achieve ecological goals in the management of large rivers, a holistic view with at least near-natural assemblages, including the names of the taxa present, should be considered in addition to functionality.

Author Contributions: Conceptualization, G.U. and Z.M.; methodology, G.U., Z.M., V.P. and M.P.U.; investigation, G.U., Z.M., V.P. and M.P.U.; validation, G.U. and Z.M.; writing-original draft preparation, G.U., Z.M., V.P. and M.P.U.; writing-review and editing, G.U., Z.M., V.P. and M.P.U.; visualization, G.U.; supervision, G.U. and Z.M.; project administration, G.U. and Z.M.; funding acquisition, G.U. and Z.M. All authors have read and agreed to the published version of the manuscript.

Funding: This research was conducted within the Slovenian-Croatian bilateral project: Benthic invertebrate based ecological status assessment of large rivers with management goals focused on hydromorphological alterations (G.U. and Z.M.). The study was also supported by the Ministry of the Environment and Spatial Planning of the Republic of Slovenia as a part of the national program for the implementation of the EU Water Framework Directive conducted at the Institute for Water of the Republic of Slovenia.

Institutional Review Board Statement: Not applicable.

Informed Consent Statement: Not applicable.

Data Availability Statement: Data are available on special request.

Acknowledgments: Authors gratefully acknowledge the members of the project teams for their assistance both in the field and in the laboratory. The Croatian Meteorological and Hydrological Service and Croatian Waters and Slovenian Environment Agency are thanked for providing hydrological and water physicochemical data. The authors would like to thank the anonymous reviewers for their useful comments to a previous version of the manuscript.

Conflicts of Interest: The authors declare no conflict of interest. The funders had no role in the design of the study; in the collection, analyses, or interpretation of data; in the writing of the manuscript, or in the decision to publish the results.

\section{Appendix A}

Table A1. Benthic invertebrate taxa recorded at near-natural sites of large rivers.

\begin{tabular}{ccc}
\hline Higher Taxon & Taxon & Abbreviations \\
\hline Turbellaria & Dendrocoelum album & \\
Turbellaria & Dendrocoelum lacteum & \\
Turbellaria & Dugesia lugubris/polychroa & \\
Turbellaria & Dugesia lugubris & \\
Turbellaria & Dugesia tigrina & \\
Turbellaria & Phagocata sp. & \\
Turbellaria & Planaria torva & \\
Turbellaria & Polycelis nigra/tenuis & \\
Nematoda & Nematoda Gen. sp. & Eis_tet \\
Oligochaeta & Enchytraeidae Gen. sp. & \\
Oligochaeta & Haplotaxis gordioides & \\
Oligochaeta & Eiseniella tetraedra & \\
Oligochaeta & Lumbriculidae Gen. sp. & \\
Oligochaeta & Lumbriculus variegatus & \\
Oligochaeta & Rhynchelmis sp. & \\
\hline
\end{tabular}


Table A1. Cont.

\begin{tabular}{|c|c|c|}
\hline Higher Taxon & Taxon & Abbreviations \\
\hline Oligochaeta & Stylodrilus heringianus & Sto_her \\
\hline Oligochaeta & Stylodrilus sp. & \\
\hline Oligochaeta & Dero sp. & \\
\hline Oligochaeta & Nais sp. & Nai_sp. \\
\hline Oligochaeta & Ophidonais serpentina & \\
\hline Oligochaeta & Pristina sp. & \\
\hline Oligochaeta & Stylaria lacustris & \\
\hline Oligochaeta & Uncinais uncinata & \\
\hline Oligochaeta & Propappus volki & \\
\hline Oligochaeta & Aulodrilus pluriseta & \\
\hline Oligochaeta & Branchiura sowerbyi & \\
\hline Oligochaeta & Tubificidae-without setae & Tubb_dae \\
\hline Oligochaeta & Tubificidae-with setae & Tubz_dae \\
\hline Hirudinea & Dina punctata & \\
\hline Hirudinea & Erpobdella nigricollis & \\
\hline Hirudinea & Erpobdella octoculata & \\
\hline Hirudinea & Erpobdella sp. & \\
\hline Hirudinea & Erpobdella testacea & \\
\hline Hirudinea & Trocheta bykowskii & \\
\hline Hirudinea & Glossiphonia complanata & \\
\hline Hirudinea & Glossiphonia concolor & \\
\hline Hirudinea & Glossiphonia nebulosa & \\
\hline Hirudinea & Helobdella stagnalis & \\
\hline Hirudinea & Hemiclepsis marginata & \\
\hline Hirudinea & Piscicola geometra & \\
\hline Gastropoda & Acroloxus lacustris & \\
\hline Gastropoda & Ancylus fluviatilis & \\
\hline Gastropoda & Bithynia tentaculata & \\
\hline Gastropoda & Borysthenia naticina & \\
\hline Gastropoda & Lithoglyphus naticoides & Lith_nat \\
\hline Gastropoda & Potamopyrgus antipodarum & \\
\hline Gastropoda & Sadleriana sp. & \\
\hline Gastropoda & Radix auricularia & \\
\hline Gastropoda & Radix balthica/labiata & \\
\hline Gastropoda & Radix balthica & \\
\hline Gastropoda & Esperiana daudebartii acicularis & \\
\hline Gastropoda & Esperiana esperi & \\
\hline Gastropoda & Holandriana holandrii & \\
\hline Gastropoda & Theodoxus danubialis & The_dan \\
\hline Gastropoda & Theodoxus transversalis & \\
\hline Gastropoda & Physa fontinalis & \\
\hline Gastropoda & Physella acuta & \\
\hline Gastropoda & Gyraulus albus & \\
\hline Gastropoda & Valvata cristata & \\
\hline Gastropoda & Valvata piscinalis & \\
\hline Gastropoda & Viviparus viviparus & \\
\hline Bivalvia & Dreissena polymorpha & \\
\hline Bivalvia & Musculium lacustre & \\
\hline Bivalvia & Pisidium sp. & \\
\hline Bivalvia & Sphaerium corneum & \\
\hline Bivalvia & Sphaerium sp. & \\
\hline Bivalvia & Sinanodonta woodiana & \\
\hline Bivalvia & Unio crassus & \\
\hline Bivalvia & Unio pictorum & \\
\hline Bivalvia & Corbicula fluminea & \\
\hline Arachnida & Hydrachnidia Gen. sp. & \\
\hline Amphipoda & Synurella ambulans & \\
\hline Amphipoda & Gammarus fossarum & Gam_fos \\
\hline Amphipoda & Gammarus roeseli & Gam_roe \\
\hline
\end{tabular}


Table A1. Cont.

\begin{tabular}{|c|c|c|}
\hline Higher Taxon & Taxon & Abbreviations \\
\hline Amphipoda & Corophium curvispinum & \\
\hline Amphipoda & Dikerogammarus haemobaphes & \\
\hline Amphipoda & Dikerogammarus villosus & \\
\hline Isopoda & Asellus aquaticus & \\
\hline Isopoda & Jaera istri & \\
\hline Ephemeroptera & Baetis buceratus & \\
\hline Ephemeroptera & Nigrobaetis digitatus & \\
\hline Ephemeroptera & Baetis fuscatus/scambus & Bae_f_s \\
\hline Ephemeroptera & Baetis lutheri & \\
\hline Ephemeroptera & Baetis rhodani & Bae_rho \\
\hline Ephemeroptera & Baetis scambus & \\
\hline Ephemeroptera & Baetis sp.-juv. & \\
\hline Ephemeroptera & Baetis vardarensis & \\
\hline Ephemeroptera & Baetis vernus & \\
\hline Ephemeroptera & Baetis buceratus/vernus & \\
\hline Ephemeroptera & Centroptilum luteolum & \\
\hline Ephemeroptera & Centroptilum sp. & \\
\hline Ephemeroptera & Cloeon dipterum & \\
\hline Ephemeroptera & Caenis sp. & \\
\hline Ephemeroptera & Serratella ignita & \\
\hline Ephemeroptera & Ephemerella notata & \\
\hline Ephemeroptera & Ephemerella mucronata & \\
\hline Ephemeroptera & Torleya major & \\
\hline Ephemeroptera & Ephemera danica & \\
\hline Ephemeroptera & Ephemera sp. & \\
\hline Ephemeroptera & Ecdyonurus sp. & \\
\hline Ephemeroptera & Epeorus sylvicola & \\
\hline Ephemeroptera & Heptagenia sp. & \\
\hline Ephemeroptera & Heptagenia sulphurea & Hep_sul \\
\hline Ephemeroptera & Rhithrogena sp. & \\
\hline Ephemeroptera & Habroleptoides confusa & \\
\hline Ephemeroptera & Paraleptophlebia submarginata & \\
\hline Ephemeroptera & Oligoneuriella rhenana & \\
\hline Ephemeroptera & Potamanthus luteus & \\
\hline Ephemeroptera & Siphlonurus sp. & \\
\hline Plecoptera & Chloroperla sp. & \\
\hline Plecoptera & Xanthoperla apicalis & \\
\hline Plecoptera & Leuctra sp. & \\
\hline Plecoptera & Nemoura sp. & \\
\hline Plecoptera & Nemurella pictetii & \\
\hline Plecoptera & Protonemura sp. & \\
\hline Plecoptera & Dinocras cephalotes & \\
\hline Plecoptera & Perla abdominalis (P. burmeisteriana) & \\
\hline Plecoptera & Marthamea vitripennis & \\
\hline Plecoptera & Isoperla sp. & \\
\hline Plecoptera & Perlodes sp. & \\
\hline Plecoptera & Brachyptera sp. & \\
\hline Plecoptera & Taeniopteryx nebulosa & \\
\hline Odonata & Calopteryx splendens & \\
\hline Odonata & Enallagma cyathigerum & \\
\hline Odonata & Ischnura elegans & \\
\hline Odonata & Coenagrionidae-juv. & \\
\hline Odonata & Cordulegaster heros & \\
\hline Odonata & Gomphus sp. & \\
\hline Odonata & Gomphus vulgatissimus & \\
\hline Odonata & Gomphus flavipes & \\
\hline Odonata & Onychogomphus forcipatus forcipatus & \\
\hline Odonata & Platycnemis pennipes & \\
\hline Heteroptera & Aphelocheirus aestivalis & \\
\hline
\end{tabular}


Table A1. Cont.

\begin{tabular}{|c|c|c|}
\hline Higher Taxon & Taxon & Abbreviations \\
\hline Heteroptera & Micronecta sp. & \\
\hline Hymenoptera & Agriotypus armatus & \\
\hline Coleoptera & Bidessus sp. Ad. & \\
\hline Coleoptera & Elmis sp. Ad. & \\
\hline Coleoptera & Elmis sp. Lv. & \\
\hline Coleoptera & Esolus sp. Ad. & \\
\hline Coleoptera & Esolus sp. Lv. & \\
\hline Coleoptera & Limnius sp. Ad. & \\
\hline Coleoptera & Limnius sp. Lv. & \\
\hline Coleoptera & Normandia nitens Ad. & \\
\hline Coleoptera & Oulimnius sp. Ad. & \\
\hline Coleoptera & Oulimnius sp. Lv. & \\
\hline Coleoptera & Stenelmis canaliculata Ad. & \\
\hline Coleoptera & Orectochilus villosus Lv. & \\
\hline Coleoptera & Haliplus sp. Lv. & \\
\hline Coleoptera & Helophorus sp. Ad. & \\
\hline Coleoptera & Hydraena sp. Ad. & \\
\hline Coleoptera & Ochthebius sp. Ad. & \\
\hline Trichoptera & Brachycentrus montanus & \\
\hline Trichoptera & Brachycentrus subnubilus & \\
\hline Trichoptera & Ecnomus tenellus & \\
\hline Trichoptera & Agapetus delicatulus/ochripes & \\
\hline Trichoptera & Agapetus laniger & \\
\hline Trichoptera & Goera pilosa & \\
\hline Trichoptera & Silo nigricornis & \\
\hline Trichoptera & Silo piceus & \\
\hline Trichoptera & Cheumatopsyche lepida & \\
\hline Trichoptera & Hydropsyche bulbifera & \\
\hline Trichoptera & Hydropsyche bulgaromanorum & \\
\hline Trichoptera & Hydropsyche contubernalis contubernalis & \\
\hline Trichoptera & Hydropsyche incognita & Hyd_inc \\
\hline Trichoptera & Hydropsyche modesta & \\
\hline Trichoptera & Hydropsyche ornatula & \\
\hline Trichoptera & Hydropsyche pellucidula & \\
\hline Trichoptera & Hydropsyche siltalai & \\
\hline Trichoptera & Hydropsyche sp.-juv. & Hyd_spj \\
\hline Trichoptera & Hydroptila sp. & \\
\hline Trichoptera & Orthotrichia sp. & \\
\hline Trichoptera & Lepidostoma hirtum & \\
\hline Trichoptera & Athripsodes albifrons & \\
\hline Trichoptera & Athripsodes sp. & \\
\hline Trichoptera & Ceraclea annulicornis & \\
\hline Trichoptera & Ceraclea dissimilis & \\
\hline Trichoptera & Mystacides azurea & \\
\hline Trichoptera & Mystacides nigra & \\
\hline Trichoptera & Oecetis lacustris & \\
\hline Trichoptera & Oecetis notata & \\
\hline Trichoptera & Setodes punctatus & \\
\hline Trichoptera & Oecetis sp. & \\
\hline Trichoptera & Anabolia furcata & \\
\hline Trichoptera & Halesus digitatus & \\
\hline Trichoptera & Limnephilinae-juv. & \\
\hline Trichoptera & Potamophylax rotundipennis & \\
\hline Trichoptera & Philoptamus ludificatus/montanus & \\
\hline Trichoptera & Polycentropus flavomaculatus & \\
\hline Trichoptera & Lype reducta & \\
\hline Trichoptera & Psychomyia pusilla & Psy_pus \\
\hline Trichoptera & Rhyacophila sp. s. str. & \\
\hline Trichoptera & Sericostoma sp. & \\
\hline
\end{tabular}


Table A1. Cont.

\begin{tabular}{|c|c|c|}
\hline Higher Taxon & Taxon & Abbreviations \\
\hline Diptera & Limnophora sp. & \\
\hline Diptera & Lispe sp. & \\
\hline Diptera & Atherix ibis & \\
\hline Diptera & Ibisia marginata & \\
\hline Diptera & Liponeura sp. & \\
\hline Diptera & Ceratopogoninae Gen. sp. & \\
\hline Diptera & Chironomini Gen. sp. & \\
\hline Diptera & Chironomus obtusidens-Gr. & \\
\hline Diptera & Chironomus thummi-Gr. & \\
\hline Diptera & Chironomus sp. & \\
\hline Diptera & Corynoneurinae Gen. sp. & \\
\hline Diptera & Diamesinae Gen. sp. & \\
\hline Diptera & Orthocladiinae Gen. sp. & Orth_nae \\
\hline Diptera & Paratendipes sp. & \\
\hline Diptera & Potthastia longimana-Gr. & \\
\hline Diptera & Procladius sp. & \\
\hline Diptera & Prodiamesa olivacea & \\
\hline Diptera & Prodiamesa rufovittata & \\
\hline Diptera & Tanypodinae Gen. sp. & \\
\hline Diptera & Tanytarsini Gen. sp. & \\
\hline Diptera & Thienemanniella sp. & \\
\hline Diptera & Dolichopodidae Gen. sp. & \\
\hline Diptera & Clinocerinae Gen. sp. & \\
\hline Diptera & Hemerodromiinae Gen. sp. & \\
\hline Diptera & Antocha sp. & Ant_sp. \\
\hline Diptera & Hexatoma sp. & \\
\hline Diptera & Limnophilinae Gen. sp. & \\
\hline Diptera & Limoniinae Gen. sp. & \\
\hline Diptera & Dicranota sp. & \\
\hline Diptera & Pedicia sp. & \\
\hline Diptera & Psychodidae Gen. sp. & \\
\hline Diptera & Prosimulium sp. & \\
\hline Diptera & Simulium sp. & Sim_sp. \\
\hline Diptera & Syrphidae Gen. sp. & \\
\hline Diptera & Chrysops sp. & \\
\hline Diptera & Tabanus sp. & \\
\hline Diptera & Tipula sp. & \\
\hline
\end{tabular}

\section{References}

1. Malmqvist, B.; Rundle, S. Threats to the running water ecosystems of the world. Environ. Conserv. 2002, 29, 134-153. [CrossRef]

2. Stoddard, J.L.; Larsen, D.P.; Hawkins, C.P.; Johnson, R.K.; Norris, R.H. Setting expectations for the ecological condition of streams: The concept of reference condition. Ecol. Appl. 2006, 16, 1267-1276. [CrossRef]

3. EU. Directive 2000/60/EC of the European Parliament and of the Council Establishing a Framework for the Community Action in the Field of Water Policy; European Commission: Brussels, Belgium, 2000; p. 72.

4. $\quad$ EEA. European Waters-Assessment of Status and Pressures 2018; EEA Report No 7/2018; European Environment Agency: Copenhagen, Denmark, 2018; p. 85.

5. EU. Communication from the Commission to the European Parliament, the European Council, the Council, the European Economic and Social Committee and the Committee of the Regions; The European Green Deal; European Commission: Brussel, Belgium, $2019 ;$ p. 24.

6. EU. EU Biodiversity Strategy for 2030. Bringing Nature Back into Our Lives; European Commission: Brussels, Belgium, $2020 ;$ p. 22.

7. Bernhardt, E.S.; Sudduth, E.B.; Palmer, M.A.; Allan, J.D.; Meyer, J.L.; Alexander, G.; Follastad-Shah, J.; Hassett, B.; Jenkinson, R.; Lave, R.; et al. Restoring rivers one reach at a time: Results from a survey of US river restoration practitioners. Restor. Ecol. 2007, 15, 482-493. [CrossRef]

8. Bernhardt, E.S.; Palmer, M.A.; Allan, J.D.; Alexander, G.; Barnas, K.; Brooks, S.; Carr, J.; Clayton, S.; Dahm, C.; Follstad-Shah, J.; et al. Synthesizing US river restoration efforts. Science 2005, 308, 636-637. [CrossRef] [PubMed]

9. Beechie, T.; Pess, G.; Roni, P.; Giannico, G. Setting River Restoration Priorities: A Review of Approaches and a General Protocol for Identifying and Prioritizing Actions. N. Am. J. Fish. Manag. 2008, 28, 891-905. [CrossRef]

10. Wohl, E.; Lane, S.N.; Wilcox, A.C. The science and practice of river restoration. Water Resour. Res. 2015, 51, 5974-5997. [CrossRef] 
11. Palmer, M.; Menninger, H.L.; Bernhardt, E. River restoration, habitat heterogeneity and biodiversity: A failure of theory or practice? Freshw. Biol. 2010, 55 (Suppl. 1), 205-222. [CrossRef]

12. Pardo, I.; Gomez-Rodriguez, C.; Wasson, J.G.; Owen, R.; Van de Bund, W.; Kelly, M.; Bennett, C.; Birk, S.; Buffagni, A.; Erba, S.; et al. The European reference condition concept: A scientific and technical approach to identify minimally-impacted river ecosystems. Sci. Total Environ. 2012, 420, 33-42. [CrossRef] [PubMed]

13. Whittier, T.R.; Hughes, R.M.; Stoddard, J.L.; Lomnicky, G.A.; Peck, D.V.; Herlihy, A.T. A structured approach for developing indices of biotic integrity: Three examples from streams and rivers in the western USA. Trans. Am. Fish. Soc. 2007, 136, 718-735. [CrossRef]

14. Tockner, K.; Uehlinger, U.; Robinson, C.T.; Tonolla, D.; Siber, R.; Peter, F.D. Introduction to European Rivers. In Rivers of Europe, 1st ed.; Tockner, K., Robinson, C.T., Uehlinger, U., Eds.; Academic Press: London, UK, 2008; pp. 1-21.

15. Copp, G.H. Typology of aquatic habitats in the Great Ouse, a small regulated lowland river. Regul. Rivers Res. Manag. 1991, 6, 125-134. [CrossRef]

16. Aarts, B.G.W.; Van den Brink, F.W.B.; Nienhuis, P.H. Habitat loss as the main cause of the slow recovery of fish faunas of regulated large rivers in Europe: The transversal floodplain gradient. River Res. Appl. 2004, 20, 3-23. [CrossRef]

17. Illies, J. Limnofauna Europaea, 2nd ed.; Gustav Fischer Verlag: Stuttgart, Germany, 1978.

18. Urbanič, G. Redelineation of European inland water ecoregions in Slovenia. Rev. Hydrobiol. 2008, 1, 17-25.

19. Urbanič, G. Hydromorphological degradation impact on benthic invertebrates in large rivers in Slovenia. Hydrobiologia 2014, 729, 191-207. [CrossRef]

20. Urbanič, G.; Mihaljević, Z.; Petkovska, V.; Pavlin Urbanič, M. Disentangling the effects of multiple stressors on large rivers using benthic invertebrates—a study of Southeastern European large rivers with implications for management. Water 2020, 12, 621. [CrossRef]

21. Purger, J.J. (Ed.) Biotas and rehabilitation of four Drava River side-branches in Hungary; Danube-Drava National Park Directorate: Pécs, Hungary, 2013; p. 164.

22. Grimmett, R.F.A.; Jones, T.A. Important Bird Areas in Europe; Technical Publication No. 9; International Council for Bird Preservation: Cambridge, UK, 1989; p. 889.

23. Schwarz, U. Pilot Study: Hydromorphological survey and mapping of the Drava and Mura Rivers. IAD-Report Prepared by FLUVIUS; Floodplain Ecology and River Basin Management: Vienna, Austria, 2007; p. 140. Available online: https://www.danube-iad.eu/ docs/reports/HydromorphIAD_Mura_Drava2007.pdf (accessed on 25 November 2019).

24. Schneider-Jacoby, M. The Sava and Drava floodplains: Threatened ecosystems of international importance. Arch. Hydrobiol. Large Rivers 2005, 16 (Suppl. 158), 249-288. [CrossRef]

25. Tavzes, B.; Urbanič, G. New indices for assessment of hydromorphological alteration of rivers and their evaluation with benthic invertebrate communities; Alpine case study. Rev. Hydrobiol. 2009, 2, 133-161.

26. OGRS. Rules on monitoring of surface water. Official Gazette of the Republic of Slovenia: Ljubljana, Slovenia, 2009; Volume 10, pp. 832-839. Available online: http://www.uradni-list.si/_pdf/2009/Ur/u2009010.pdf (accessed on 12 June 2021).

27. Hrvatske vode. Sampling Methodology, Laboratory Analysis and Calculation of Ecological Quality Ratio Based on Biological Quality Elements; Hrvatske vode: Zagreb, Croatia, 2016.

28. Mihaljević, Z.; Urbanič, G.; Ternjej, I. Ecological status assesment system for large rivers based on macrozoobenthos. In Proceedings of the 7th Croatian Water Conference Proceedings, Dubrovnik, Croatia, 2-7 June 2002; Biondić, D., Holjević, D., Vizner, M., Eds.; Hrvatske Vode: Zagreb, Croatia, 2019; pp. 371-380. (In Croatian with English Summary)

29. Mihaljević, Z.; Miliša, M.; Pozojević, I. Report on Fitting a Macroinvertebrate Classification Method with the Results of the Completed Intercalibration of the EC GIG (R-E2 and R-E3); Hrvatske Vode: Zagreb, Croatia, 2020.

30. CLC. CORINE Land Cover 2012; European Environment Agency: Copenhagen, Denmark, 2012.

31. Petkovska, V.; Urbanič, G.; Mikoš, M. Variety of the guiding image of rivers-defined for ecologically relevant habitat features at the meeting of the Alpine, Mediterranean, lowland and karst regions. Ecol. Eng. 2015, 81, 373-386. [CrossRef]

32. Raven, P.J.; Holmes, N.T.H.; Dawson, F.H.; Fox, P.J.A.; Everard, M.; Fozzard, I.R.; Rouen, K.J. River Habitat Survey in Britain and Ireland Field Survey Guidance Manual: Version 2003; Environment Agency: 2003. Available online: https://assets.publishing. service.gov.uk/government/uploads/system/uploads/attachment_data/file/311579/LIT_1758.pdf (accessed on 22 February 2020).

33. Raven, P.J.; Holmes, N.T.H.; Dawson, F.H.; Fox, P.J.A.; Everard, M.; Fozzard, I.R.; Rouen, K.J. River Habitat Quality the Physical Character of Rivers and Streams in the UK and Isle of Man; River Habitat survey Report No. 2; Environment Agency: London, UK, 1998; p. 86.

34. Urbanič, G. Ecological status assessment of rivers in Slovenia-An overview. Nat. Slov. 2011, 13, 5-16.

35. Pavlin, M.; Birk, S.; Hering, D.; Urbanič, G. The role of land use, nutrients, and other stressors in shaping benthic invertebrate assemblages in Slovenian rivers. Hydrobiologia 2011, 678, 137-153. [CrossRef]

36. AQEM Consortium. Manual for the application of the AQEM system. In A Comprehensive Method to Assess European Streams Using Benthic Macroinvertebrates, Developed for the Purpose of the Water Framework Directive. Version 1. 2002, p. 198. Available online: http:/ / www.aqem.de/mains/products.php (accessed on 22 February 2020).

37. Urbanič, G.; Toman, M.J.; Krušnik, C. Microhabitat type selection of caddisfly larvae (Insecta: Trichoptera) in a shallow lowland stream. Hydrobiologia 2005, 541, 1-12. [CrossRef] 
38. Anderson, M.J. A new method for non-parametric multivariate analysis of variance. Aust. Ecol. 2001, $26,3$.

39. Clarke, K.R. Non-parametric multivariate analysis of changes in community structure. Aust. J. Ecol. 1993, 18, 117-143. [CrossRef]

40. McCune, B.; Grace, J.B. Analysis of Ecological Communities. J. Exp. Mar. Biol. Ecol. 2002, 28, 289.

41. Hammer, Ø.; Harper, D.A.T.; Ryan, P.D. PAST: Paleontological statistics software package for education and data analysis. Palaeontol. Electron. 2001, 4, 1-210.

42. Popijać, A.; Sivec, I. Stonefly (Plecoptera) fauna in the lower reach of the Una river in Croatia. Entomol. Croat. 2011, 15, 131-143.

43. Zwick, P. Key to the West Palaearctic genera of stoneflies (Plecoptera) in the larval stage. Limnologica 2004, 34, 315-348. [CrossRef]

44. Vučković, N.; Pozojević, I.; Urbanič, G.; Mihaljević, Z. New evidence supporting upstream pathways of Hypania invalida (Grube, 1860) invasion. BioInvasions Rec. 2021, 10, 589-597. [CrossRef]

45. Ketelaars, H.A.M. Range extensions of Ponto-Caspian aquatic invertebrates in Continental Europe. In Aquatic Invasions in the Black, Caspian, and Mediterranean Seas; Dumont, H., Ed.; Kluwer Academic Publishers: Amsterdam, The Netherlands, 2004; pp. 209-236.

46. Pavel, A.B.; Menabit, S.; Pop, I.C.; Stanescu, I.; Naliana, L. The spatio-temporal distribution of the Ponto-Caspian polychaete in the Lower Sector of the Danube River and in Danube Delta. Glob. Ecol. Conserv. 2021, 28, e01623. [CrossRef]

47. Birk, S.; Willby, N.J.; Kelly, M.G.; Bonne, W.; Borja, A.; Poikane, S.; van de Bund, W. Intercalibrating classifications of ecological status: Europe's quest for common management objectives for aquatic ecosystems. Sci. Total Environ. 2013, 454, 490-499. [CrossRef] [PubMed]

48. Moss, B. Mammals, freshwater reference states, and the mitigation of climate change. Freshw. Biol. 2015, 60, 1964-1976. [CrossRef]

49. Petsch, D.K. Causes and consequences of biotic homogenization in freshwater ecosystems. Int. Rev. Hydrobiol. 2016, 101, 113-122. [CrossRef]

50. Rinaldi, M.; Gurnell, A.M.; del Tanago, M.G.; Bussettini, M.; Hendriks, D. Classification of river morphology and hydrology to support management and restoration. Aquat. Sci. 2016, 78, 17-33. [CrossRef]

51. Allan, J.D.; Castillo, M.M. Stream Ecology: Structure and Function of Running Waters, 2nd ed.; Springer: Amsterdam, The Netherlands, 2007; p. 436.

52. Allan, J.D. Structure and Function of Running Waters. In Stream Ecology; Chapman \& Hall: London, UK, $1995 ;$ p. 388.

53. Belletti, B.; de Leaniz, C.G.; Jones, J.; Bizzi, S.; Börger, L.; Segura, G.; Castelletti, A.; van de Bund, W.; Aarestrup, K.; Barry, J.; et al. More than one million barriers fragment Europe's rivers. Nature 2020, 588, 436-441. [CrossRef] [PubMed]

54. Knehtl, M.; Podgornik, S.; Urbanič, G. Scale-depended effects of hydromorphology and riparian land-use on benthic invertebrates and fish: Implications for large river management. Hydrobiologia 2021, 23, 1-21. [CrossRef]

55. Sun, J.; Galib, S.M.; Lucas, M.C. Rapid response of fish and aquatic habitat to removal of a tidal barrier. Aquat. Conserv. Mar. Freshw. Ecosyst. 2021, 31, 1802-1816. [CrossRef]

56. Downes, B. Back to the future: Little-used tools and principles of scientific inference can help disentangle effects of multiple stressors on freshwater ecosystems. Freshw. Biol. 2010, 55 (Suppl. 1), 60-79. [CrossRef]

57. Schinegger, R.; Trautwein, C.; Melcher, A.; Schmutz, S. Multiple human pressures and their spatial patterns in European running waters. Water Environ. J. 2012, 26, 261-273. [CrossRef] [PubMed]

58. Dodds, W.K.; Whiles, M.R. Freshwater Ecology. In Concepts and Environmental Applications of Limnology, 3rd ed.; Academic Press: Cambridge, MA, USA, 2019; p. 998. 